\title{
PENGARUH PENAMBAHAN MULTI NUTRIENT SAUCE DALAM RANSUM TERHADAP KECERNAAN BAHAN KERING DAN BAHAN ORGANIK PADA DOMBA
}

\author{
The Effect of Addition of Multi Nutrient Sauce in Rations on Digestibility of Dry Matter and Organic \\ Matter in Sheep
}

\author{
Yogi Ramdani, Erwanto, Farida Fathul, dan Liman
}

Department of Animal Husbandry, Faculty of Agriculture, University of Lampung

Jl. Prof. Dr. Soemantri Brojonegoro No.1 Gedong Meneng Bandar Lampung 35145

e-mail : yogi.ramdani46@gmail.com

\begin{abstract}
This study aimed to investigate the effect of adding multi nutrient sauce to rations on the digestibility of dry matter and organic matter in sheep. This research was conducted in May--July 2019 in Kebagusan Village, Gedong Tataan District, Pesawaran Regency. Analysis of feed ingredients and feces was carried out at the Animal Nutrition and Feed Laboratory, Department of Animal Husbandry, Faculty of Agriculture, University of Lampung. This research was conducted experimentally using the Randomized Block Design (RBD) method. Sheep were divided into six groups based on body weight, namely group 1 $(11,18--13,18 \mathrm{~kg})$, group $2(13,97--14,13 \mathrm{~kg})$, group $3(14,31--14,51 \mathrm{~kg})$, group $4(14,89--15,91 \mathrm{~kg})$, group $5(16,35--16,66 \mathrm{~kg})$, and group $6(17,15--17,77 \mathrm{~kg})$. Each group consisted of 3 sheep. Treatment given were R0: basal ration formulated by farmer (forage silage + cassava byproduct), R1: R0 $+5 \%$ multi nutrient sauce, R2: R0 $+10 \%$ multi nutrient sauce. The results showed that the addition of $10 \%$ multi nutrient sauce was the best treatment that could improve the digestibility of dry matter and organic matter in sheep.
\end{abstract}

Key word : Multi nutrient sauce, Dry matter digestibility, Digestibility of organic matter, Sheep.

\begin{abstract}
ABSTRAK
Penelitian ini bertujuan untuk mengetahui pengaruh penambahan multi nutrient sauce dalam ransum terhadap kecernaan bahan kering dan bahan organik pada domba. Penelitian ini dilaksanakan pada Mei-Juli 2019 di Desa Kebagusan, Kecamatan Gedong Tataan, Kabupaten Pesawaran. Analisis bahan pakan dan feses dilakukan di Laboratorium Nutrisi dan Makanan Ternak, Jurusan Peternakan, Fakultas Pertanian, Universitas Lampung. Penelitian ini dilakukan secara eksperimen menggunakan metode Rancangan Acak Kelompok (RAK). Ternak domba dibagi menjadi 6 kelompok berdasarkan bobot badan yaitu: Kelompok 1 (11,18--13,18 kg), kelompok 2 (13,97--14,13 kg), kelompok 3 (14,31--14,51 kg), kelompok 4 (14,89--15,91 kg), kelompok 5 (16,35--16,66 kg), kelompok 6 (17,15--17,37 kg). Masingmasing kelompok terdiri atas 3 ekor domba. Perlakuan yang diberikan R0: ransum asal petani (silase hijauan + onggok), R1: R0 $+5 \%$ multi nutrient sauce, R2: R0 + 10\% multi nutrient sauce. Hasil penelitian menunjukkan bahwa penambahan multi nutrient sauce $10 \%$ merupakan perlakuan terbaik yang mampu meningkatkan kecernaan bahan kering dan bahan organik pada domba.
\end{abstract}

Kata kunci : Multi nutrient sauce, Kecernaan bahan kering, Kecernaan bahan organik, Domba.

\section{PENDAHULUAN}

Penggunaan ransum pada ternak harus memiliki kandungan nutrien yang mampu memenuhi kebutuhan dari ternak. Terpenuhinya unsur-unsur mikro berupa mineral dan vitamin maupun asam amino tertentu yang biasanya tidak diperoleh ternak di dalam ransum, maka diperlukan pakan tambahan atau supplemen untuk menunjang kebutuhan pokok dan produksi dari ternak. Salah satunya dengan penambahan Multi Nutrient Sauce (MNS) di dalam ransum sebagai suplemen tambahan dalam ransum.

Multi Nutrient Sauce (MNS) merupakan pengembangan suplemen ransum ternak bergizi tinggi yang dapat meningkatkan keefektifan kerja mikrobia didalam rumen ternak ruminansia. Suplemen tersebut terdiri dari molasses, urea, garam, dolomit, vitamin dan mineral yang akan berfungsi untuk meningkatkan palatabilitas dan nutrisi ransum 
berkualitas rendah yang diharapkan akan meningkatkan kosumsi bahan kering dan bahan organik pada domba yang juga akan berdampak pada kecernaan kecernaan bahan kering dan bahan organik pada domba. Berdasarkan uraian diatas Penelitian ini dilakukan untuk mengetahui pengaruh penggunaan MNS dalam ransum domba terhadap kecernaan bahan kering dan bahan organik pada domba.

\section{MATERI DAN METODE}

\section{Waktu dan tempat}

Penelitian ini dilaksanakan pada Mei-Juli 2019, bertempat di Peternakan Rakyat di Desa Kebagusan, Kecamatan Gedong Tataan, Kabupaten Pesawaran. Analisis bahan pakan dan feses dilakukan di Laboratorium Nutrisi dan Makanan Ternak, Jurusan Peternakan, Fakultas Pertanian, Universitas Lampung.

\section{Bahan dan Alat}

Peralatan yang digunakan adalah kandang berkapasitas 18 ekor domba dengan tempat makan, minum, timbangan, dan waring. Bahan yang digunakan dalam penelitian ini adalah 18 ekor domba jantan yang dipelihara secara intensif pada kandang individu. Ransum perlakuan (R0, R1, R2) berupa ransum basal (formulasi ransum yang digunakan peternak) yang diberikan formula MNS dengan level yang berbeda, bahan penyusun MNS yaitu Urea, Molasses, Dolomit, Garam, mineral, dan vitamin, serta air minum yang diberikan secara ad libitum.

\section{Metode Penelitian}

Penelitian ini dilakukan secara eksperimen menggunakan metode Rancangan Acak Kelompok (RAK). Ternak domba dibagi menjadi 6 kelompok berdasarkan bobot badan yaitu:

Kelompok 1: (11,18--13,18 kg);

Kelompok 2: (13,97--14,13 kg);

Kelompok 3: (14,31--14,51 kg);

Kelompok 4: (14,89--15,91 kg);

Kelompok 5: (16,35--16,66 kg),

Kelompok 6: (17,15--17,37 kg).

Masing-masing kelompok terdiri atas 3 ekor domba.

Perlakuan yang diberikan pada domba adalah : R0: Ransum basal petani (silase + onggok);

$\mathrm{R} 1: \mathrm{R} 0+5 \%$ Multi Nutrient Sauce;

R2: R0 + 10\% Multi Nutrient Sauce.
Formulasi multi nutrient sauce $100 \%$ terdapat pada Tabel 1.

Tabel 1. Formulasi multi nutrient sauce $100 \%$

\begin{tabular}{lc}
\hline Nama bahan & Presentase $(\%)$ \\
\hline Molasses & 67,7 \\
Urea & 09,9 \\
Garam & 07,9 \\
Dolomit & 07,9 \\
Mineral vitamin & 06,6 \\
\hline Total & 100 \\
\hline
\end{tabular}

Imbangan nutrien pada ransum perlakuan terdapat pada Tabel 2 .

Tabel 2. Imbangan nutrien pada ransum perlakuan

\begin{tabular}{lccc}
\hline \multirow{2}{*}{ kandungan } & \multicolumn{3}{c}{ Perlakuan } \\
\cline { 2 - 4 } & R0 & R1 & R2 \\
\cline { 2 - 4 } & $------------\%$----------- \\
\hline Bahan kering & 77,87 & 78,01 & 78,15 \\
Proterin kasar & 11,89 & 12,93 & 13,41 \\
Lemak kasar & 11,29 & 10,76 & 10,28 \\
Serat kasar & 21,59 & 20,58 & 19,66 \\
Abu & 12,11 & 11,85 & 11,69 \\
BETN & 20,99 & 22,40 & 24,28 \\
TDN & 60,97 & 60,09 & 59,78 \\
\hline
\end{tabular}

\section{Peubah yang Diamati}

Peubah yang diamati adalah Kecernaan bahan kering dan kecernaan bahan organik Domba.

\section{Analisis Data}

Data yang diperoleh dianalisis dengan menggunakan analisis ragam dan dilanjutkan dengan uji Beda Nyata Terkecil (BNT) pada taraf $0,05 \%$.

\section{HASIL DAN PEMBAHASAN}

Pengaruh Penambahan Multi Nutrient Sauce pada ransum Terhadap Kecernaan Bahan Kering pada Domba

Kecernaan adalah indikasi awal ketersediaan berbagai nutrisi yang terkandung dalam bahan pakan tertentu bagi ternak yang mengkonsumsinya. Semakin tinggi kecernaan bahan kering maka semakin tinggi juga peluang nutrisi yang dapat dimanfaatkan ternak untuk pertumbuhannya (Hardana et al., 2013). Bahan kering merupakan total zat dari makanan yang tidak termasuk air di dalamnya.

Hasil analis ragam pada penelitian ini menunjukkan bahwa penambahan multi nutrient sauce pada ransum berpengaruh nyata $(\mathrm{P}<0,05)$ terhadap kecernaan bahan kering ransum domba. Diduga dengan penambahan MNS yang 
bahan penyusun MNS yaitu molasses, urea, garam, dolomit, mineral,dan vitamin mampu meningkatkan daya kerja mikroba dalam rumen yang dapat mempengaruhi daya cerna ransum. Salah satu kandungan dari MNS tersebut yaitu molasses mampu meningkatkan kerja dari mikroorganisme dalam rumen. Hal ini, didukung oleh Sari (1989) bahwa penambahan molasses pada ransum mengakibatkan mikroorganisme dalam rumen mampu merombak serat kasar pada dinding sel, sehingga serat kasar lebih cepat dicerna. Disebutkan juga meningkatnya penambahan molases akan meningkatkan daya cerna dari ternak, karena molasses merupakan sumber karbohidrat yang mudah larut selain itu terdapat banyak energi yang terkandung dalam molasses yang mempengaruhi pertumbuhan dari mikroorganisme dalam rumen.

Selain pemberian molasses, pemberian urea juga mampu mempengaruhi keceranaan ransum pada ternak. Hal ini, sesuai dengan pernyataan Bolsen, et al. (1992) menyatakan bahwa urea yaitu senyawa yang mengandung unsur nitrogen yang cukup tinggi sekitar $46 \%$ sehingga dapat menyokong perkembangbiakan bakteri dan dapat digunakan pada sintesa protein mikrobial. Data penelitian ini disajikan pada Tabel 3 .

Tabel 3. Pengaruh perlakuan penambahan multi nutrinet sauce terhadap kecernaan bahan kering domba

\begin{tabular}{cccc}
\hline \multirow{2}{*}{ Kelompok } & \multicolumn{3}{c}{ Perlakuan pada ransum } \\
\cline { 2 - 4 } & R0 & R1 & R2 \\
\cline { 2 - 4 } & $-------------0 \%-------------$ \\
\hline 1 & 38,33 & 41,17 & 45,36 \\
2 & 38,28 & 45,83 & 52,59 \\
3 & 41,06 & 49,85 & 51,62 \\
4 & 46,54 & 41,99 & 49,11 \\
5 & 42,50 & 36,65 & 50,08 \\
6 & 36,92 & 46,04 & 51,21 \\
\hline \multirow{2}{*}{ Rataan } & $40,61 \pm$ & $43,59 \pm$ & $50,00 \pm$ \\
& $3,55^{\mathrm{a}}$ & $4,62^{\mathrm{a}}$ & $2,57^{\mathrm{b}}$ \\
\hline
\end{tabular}

Keterangan: Nilai dengan huruf superskrip yang berbeda pada baris yang sama menunjukkan berbeda nyata $(\mathrm{P}<0,05)$ berdasarkan Uji BNT

R0: Ransum Basal Petani

$\mathrm{R} 1: \mathrm{R} 0+5 \%$ multi nutrient sauce

$\mathrm{R} 2: \mathrm{R} 0+10 \%$ multi nutrient sauce

Hasil uji lanjut BNT menunjukkan bahwa hasil KcBK tertinggi terdapat pada perlakuan penambahan $10 \%$ multi nutrient sauce jika dibandingkan dengan perlakuan lainnya. Penambahan 10\% MNS merupakan penambahan yang paling banyak ditambahkan pada ransum yang artinya semakin banyak MNS yang diberikan pada ransum maka akan semakin mempengaruhi $(\mathrm{P}<0,05)$ kecernaan bahan kering pada ternak. Akan tetapi pada perlakuan tanpa pemberian MNS dan pemberian MNS 5\% diperoleh nilai $\mathrm{KcBK}$ yang terendah dan antara keduanya tidak berbeda nyata $(\mathrm{P}>0,05)$. Hasil penelitian ini menunjukkan bahwa dengan penambahan multi nutrient sauce 5\% belum efektif untuk meningkatkan keceranaan bahan kering.

Kandungan bahan kering tertinggi terdapat pada perlakuan penambahan multi nutrient sauce $10 \%$ dibandingkan dari perlakuan lainnya. Semakin banyaknya kandungan bahan kering pada ransum maka dapat meningkatkan kecernaan bahan kering pada ternak pada ternak. Hal ini didukung oleh pernyataan Zain (1999) bahwa tingkat konsumsi ransum akan mempengaruhi kecernaan. Selanjutnya, Tillman, et al., (1998) menyatakan bahwa faktor yang mempengaruhi tingkat kecernaan bahan kering salah satunya adalah jumlah bahan kering yang dikonsumsi karena aktivitas mikroba mengikuti bahan pakan yang dikonsumsi. Kemudian ditambahkan oleh pendapat Kamal (1994) jika konsumsi pakan meningkat diduga pertumbuhan dan perkembangan mikrobanya juga meningkat.

Hasil yang di dapatkan pada penambahan multi nutrient sauce $10 \%$ pada ransum tersebut juga menunjukkan bahwa dosis yang diberikan masih dapat digunakan dengan baik oleh ternak untuk meningkatkan pertumbuhan dan aktivitas mikroba rumen, sehingga kecernaan bahan kering ransum dapat meningkat dan meperbaiki kualitas ransum dari ternak domba. Hal ini, didukung oleh pernyataan Arora (1996) bahwa Kecernaan bahan pakan tergantung pada gerak laju makanan di dalam saluran pencernaan, sedangkan laju makanan dipengaruhi oleh jenis makanan yang dikonsumsi. Apabila diberikan pakan yang memiliki nilai nutrisi tinggi maka nilai kecernaan zat makanan tersebut akan meningkat.

\section{Pengaruh Penambahan Multi Nutrient Sauce pada Ransum TerhadapKecernaan Bahan Organik pada Domba \\ Hasil analis ragam pada penelitian ini} menunjukkan bahwa penambahan multi nutrient sauce (MNS) pada ransum berpengaruh nyata $(\mathrm{P}<0,05)$ terhadap kecernaan bahan organik ransum domba. Hal ini berarti penambahan MNS dengan bahan penyusun MNS yaitu molasses, urea, garam, dolomit, mineral dan vitamin mampu meningkatkan daya kerja mikroba dalam rumen yang akan mempengaruhi daya cerna dari ternak domba. Data penelitian ini disajikan pada Tabel 4. 
Tabel 4. Pengaruh perlakuan penambahan multi nutrinet sauce terhadap kecernaan bahan organik domba

\begin{tabular}{cccc}
\hline \multirow{2}{*}{ Kelompok } & \multicolumn{3}{c}{ Perlakuan pada ransum } \\
\cline { 2 - 4 } & R0 & R1 & R2 \\
\cline { 2 - 4 } 1 & 42,99 & 47,37 & 52,98 \\
2 & 41,98 & 51,01 & 58,17 \\
3 & 44,75 & 54,64 & 57,18 \\
4 & 52,35 & 47,05 & 54,86 \\
5 & 49,19 & 40,65 & 55,82 \\
6 & 42,44 & 51,68 & 55,82 \\
\hline \multirow{2}{*}{ Rataan } & $45,62 \pm$ & $48,73 \pm$ & $55,81 \pm$ \\
& $4,22^{\mathrm{a}}$ & $4,87^{\mathrm{a}}$ & $1,81^{\mathrm{b}}$ \\
\hline
\end{tabular}

Keterangan: Nilai dengan huruf superscript yang berbeda pada baris yang sama menunjukkan berbeda nyata $(\mathrm{P}<0,05)$ berdasarkan Uji BNT

R0: Ransum Basal Petani

$\mathrm{R} 1: \mathrm{R} 0+5 \%$ multi nutrient sauce

$\mathrm{R} 2: \mathrm{R} 0+10 \%$ multi nutrient sauce

Hasil uji lanjut BNT menunjukkan bahwa hasil KcBO tertinggi terdapat pada perlakuan penambahan $10 \%$ multi nutrient sauce hasil tertinggi dibandingkan dengan perlakuan lainnya. Penambahan 10\% MNS merupakan penambahan yang paling banyak ditambahkan pada ransum yang artinya semakin banyak MNS yang diberikan pada ransum maka akan semakin mempengaruhi $(\mathrm{P}<0,05)$ kecernaan bahan organik pada ternak, akan tetapi pada perlakuan tanpa pemberian MNS dan pemberian MNS 5\% diperoleh nilai $\mathrm{KcBO}$ yang terendah yang berarti tidak berbeda nyata $(\mathrm{P}>0,05)$.

Kandungan protein kasar tertinggi terdapat pada perlakuan penambahan multi nutrient sauce $10 \%$ dibandingkan dari perlakuan lainnya. Semakin banyaknya kandungan protein pada ransum maka akan meningkatkan kecernaan bahan organik pada ternak. Hal ini didukung oleh Harris (1970) menyatakan bahwa kecernaan bahan organik dalam saluran pencernaan ternak meliputi kecernaan zat-zat pakan berupa komponen bahan organik meliputi karbohidrat, protein, lemak, dan vitamin. Maka semakin banyak protein yang diberikan pada ternak kecernaan bahan organik pada ternak akan meningkat. Ransum yang kandungan proteinnya rendah, umumnya mempunyai kecernaan yang rendah pula dan sebaliknya. Tinggi rendahnya kecernaan protein tergantung pada kandungan protein bahan pakan dan banyaknya protein yang masuk dalam saluran pencernaan (Tillman, et al., 1998).

Kandungan serat kasar paling rendah terdapat pada perlakuan penambahan multi nutrient sauce $10 \%$ dibandingkan dari perlakuan lainnya. Semakin rendahnya kandungan serat kasar pada ransum maka akan meningkatkan kecernaan bahan organik pada ternak. Hal ini didukung oleh pernyataan Tillman, et al., (1998) bahwa kecernaan bahan organik juga dipengaruhi oleh kandungan serat kasar dalam bahan pakan sebab kandungan serat kasar dalam pakan akan mengakibatkan rendahnya nilai degradasi, karena serat kasar yang berupa selulosa dan hemiselulosa sering berikatan dengan lignin dan akan sulit untuk dipecah oleh enzim pencernaan, dengan demikian kecernaan akan semakin rendah apabila suatu bahan pakan mengandung serat yang tinggi. Rendahnya kandungan serat kasar pada penambahan multi nutrient sauce 10\% membuat keceranaan bahan organik semakin tinggi.

Kadar bahan organik dalam ransum diperoleh dari bahan kering dalam ransum dikurang dengan kadar abu dalam ransum. Hal ini, didukung pernyataan Parakkasi (1999) yang menyatakan bahwa bahan organik merupakan bahan kering yang telah dikurangi abu, komponen bahan kering bila difermentasi di dalam rumen akan menghasilkan asam lemak terbang yang merupakan sumber energi bagi ternak. Kecernaan bahan organik dalam saluran pencernaan ternak meliputi kecernaan zat-zat makanan berupa komponen bahan organik seperti karbohidrat, protein, lemak dan vitamin.

Selanjutnya, menurut Tillman, et al., (1991) bahwa bahan organik merupakan bahan yang hilang pada saat pembakaran. Nutrien yang terkandung dalam bahan organik merupakan komponen bahan penyusun bahan kering. Komposisi bahan organik terdiri dari lemak, protein kasar, serat kasar dan BETN. Semakin tinggi kandungan bahan organik pada ransum maka kecernaannya akan meningkat. Hal ini sesuai dengan pernyataan Wodzicka, et al., (1991) bahwa tinggi rendahnya kecernaan bahan organik disebabkan oleh tinggi rendahnya konsumsi bahan organik. Besarnya konsumsi bahan organik ini akan berpengaruh terhadap ketersediaan energi dalam rumen untuk pertumbuhan mikroba rumen. Pertumbuhan mikroba rumen akan berhubungan dengan kerja optimal mikroba yang nantinya berpengaruh terhadap kecernaan ternak (Kamal, 1994), sehingga konsumsi bahan organik akan berbanding lurus dengan kecernaan bahan organiknya.

Selain kadar bahan organik kandungan BETN tertinggi terdapat pada perlakuan penambahan multi nutrient sauce $10 \%$ dibandingkan dari perlakuan lainnya. Semakin tinggi kandungan BETN dalam pakan atau 
ransum yang diberikan pada ternak maka kecernaan bahan organiknya akan semakin tinggi. Hal ini didukung oleh pernyataan Hastuti, et al., (2011) bahwa dalam aktivitasnya mikroba menggunakan sumber energi karbohidrat mudah dicerna (BETN) sebagai langkah awal untuk pertumbuhan dan berkembang biak.

Selanjutnya, ditambahkan oleh pendapat Tillman, et al., (1998) bahwa karbohidrat dibagi menjadi dua golongan yaitu SK dan BETN atau nitrogen free extract. Berdasarkan fraksi hasil analisis proksimat, BETN terdiri dari beberapa komponen antara lain selulosa, hemiselulosa, lignin, gula fruktan, pati, pectin, asam organik, resin, tannin, pigmen dan vitamin-vitamin yang mudah larut dalam air. Lignin pada BETN diperoleh dari analisis SK yang sebagian dipisahkan dengan ekstraksi alkali lemak sehingga mengurangi SK dan mengakibatkan BETN pakan akan naik.

Hasil dari penelitian menunjukkan bahwa peningkatan kecernaan bahan kering ransum selalu diiringi dengan peningkatan kecernaan bahan organik ransum. Karena, kecernaan bahan kering merupakan bagian dari kecernaan bahan organik. Menurut Sutardi (1980), bahan organik merupakan bagian dari bahan kering, sehingga meningkatnya konsumsi bahan kering maka konsumsi bahan organik akan meningkat pula. Peningkatan kecernaan bahan organik sejalan dengan meningkatnya kecernaan bahan kering, karena sebagian besar komponen bahan kering terdiri atas bahan organik sehingga faktor-faktor yang mempengaruhi tinggi rendahnya kecernaan bahan kering akan berpengaruh juga terhadap tinggi rendahnya kecernaan bahan organik.

\section{KESIMPULAN}

Berdasarkan penelitian yang telah dilaksanakan dapat disimpulkan bahwa :

1. Penambahan multi nutrient sauce pada ransum berpengaruh nyata meningkatkan kecernaan bahan kering (KcBK) dan kecernaan bahan organik $(\mathrm{KcBO})$ pada domba,

2. Penambahan $10 \%$ multi nutrient sauce pada ransum memberikan pengaruh terbaik pada kecernaan bahan kering (KcBK) dan kecernaan bahan organik $(\mathrm{KcBO})$ ransum domba.

\section{DAFTAR PUSTAKA}

Arora. 1996. Pencernaan Mikroba pada Ruminansia. Diterjemahkan oleh R. Murwani dan B. Srigandono. Gajah Mada University Press. Yogyakarta.

Bolsen, K.K., G. Ashbell., and J.M. Wilkinson, 1992. Silage Additifs in Biotechnology in Animal Feeds and Animal Feeding. R.J. Wallace and A. Chesson Eds. VCH, Weinheim.

Hardana, N.E., Suparwi, dan F.M. Suhartati. 2013. Fermentasi kulit buah kakao (Theobroma cacao L.) menggunakan Aspergillus niger pengaruhnya terhadap kecernaan bahan kering (KBK) dan kecernaan bahan organik (KBO) secara in vitro. J Ilmu Peternakan. 1:781-788.

Harris, L. E. 1970. Nutrition Research Techniques for Domestic and Wild Animals. Volume 1. An International Record System and Procedures for Analyzing Samples. Animal Science Department. Utah State University. Logan. Utah.

Hastuti, D., S. Nur, B. Iskandar. 2011. Pengaruh perlakuan teknologi amofer (amoniasi fermentasi) pada limbah tongkol jagung sebagai alternatif pakan berkualitas ternak ruminansia. Jurnal Ilmu-Ilmu Pertanian. 7(1):55--65.

Kamal, M. 1994. Nutrisi Ternak I. Fakultas Peternakan, Universitas Gadjah Mada. Yogyakarta.

Parakkasi, A. 1999. Ilmu Nutrisi dan Makanan Ternak Ruminan. Cetakan Pertama Penerbit UP. Jakarta.

Sari, R. 1989. Pengaruh berbagai level urea molasses block terhadap kecernaan bahan kering dan bahan organik pada kerbau (Bubalus bubalis). Karya Ilmiah. Fakultas Peternakan. Institut Pertanian Bogor. Bogor.

Sutardi, T. 1980. Landasan Ilmu Nutrisi Jilid I. Departemen Ilmu Makanan Ternak, Fakultas Pertanian. Institut Pertanian Bogor. Bogor.

Tillman, A.D., S. Reksohadiprojo, S. Prawirokusumo, dan S. Lebdosoekojo. 1991. Ilmu Makanan Ternak Dasar Cetakan ke-5. Gadjah Mada University Press. Yogyakarta.

Tillman, A.D., H. Hartadi, S. Reksohadiprojo, S. Prawirokusumo, dan S. Lebdosoekojo. 1998. Ilmu Makanan Ternak Dasar. Edisi Keenam. Gadjah Mada University Press. Yogyakarta. 
Wodzicka-Tomaszewska, M.I.K., I. Sutama, Putu dan D. Thamrin. Chaniago. 1991. Reproduksi. Tingkah Laku dan Produksi Ternak di indonesia. Gramedia Pustaka Utama. Jakarta.

Zain, M. 1999. Pengaruh taraf bungkil biji kapok dalam ransum kambing perah laktasi Terhadap kecernaan dan karakteristik kondisi rumen. Jurnal Peternakan dan Lingkungan. 5: 32-34. 